\title{
Biopolyphenolics as antioxidants: Studies under an Indo-Italian CSIR-CNR project*
}

\author{
Mario C. Foti ${ }^{1, \ddagger}$, Sunil K. Sharma ${ }^{2}$, Gaurav Shakya ${ }^{2}$, \\ Ashok K. Prasad ${ }^{2}$, Giovanni Nicolosi ${ }^{1}$, Paolo Bovicelli ${ }^{3}$, \\ Balaram Ghosh ${ }^{4}$, Hanumantharao G. Raj ${ }^{5}$, Ramesh C. Rastogi ${ }^{2}$, \\ and Virinder S. Parmar ${ }^{2}$
}

${ }^{1}$ Istituto di Chimica Biomolecolare del CNR, Sezione di Catania, Via del Santuario 110, 95028 Valverde (CT), Italy; ${ }^{2}$ Bioorganic Laboratory, Department of Chemistry, University of Delhi, Delhi 110 007, India; ${ }^{3}$ stituto di Chimica Biomolecolare, CNR, Sezione di Roma, University of La Sapienza, I-00185, Roma, Italy; ${ }^{4}$ Molecular Immunology and Immunogenetics Laboratory, Institute of Genomics and Integrative Biology, Mall Road, Delhi 110 007, India; ${ }^{5}$ Department of Biochemistry, V. P. Chest Institute, University of Delhi, Delhi 110 007, India

\begin{abstract}
A wide variety of polyphenolic compounds (i.e., 4-methylcoumarins, xanthones, pyrazoles, and pyrazolylacrylonitriles) have been examined for their antioxidant effect on NADPH-catalyzed liver-microsomal lipid peroxidation with a view to establishing their structure-activity relationship. Dihydroxy-/diacetoxy-4-methylcoumarin derivatives have been shown to be radical scavengers. The effect of nine different xanthones has been examined on the modulation of cytokine-induced expression of intercellular adhesion molecule-1 (ICAM-1) in human endothelial cells. 1,4-Dihydroxyxanthone showed enhanced antioxidant activity as well as ICAM-1 inhibitory activity.
\end{abstract}

\section{INTRODUCTION}

Considerable progress has been made in recent years in relating aging to oxidation in biological cells. The reactive oxygen species (ROS), causing oxidation in biological cells, are mainly involved in detoxification of invading organisms and chemicals, but stray ROS also initiate lipid peroxidation in healthy cells. Lipid peroxidation initiated by oxygen radicals eventually results in membrane degradation and cell death [1], leading to diverse pathologies such as Alzheimer's disease, atherosclerosis, diabetes, Parkinson's disease, etc. [2]. Thus, reduction of the rate of these life-limiting metabolic processes by use of chemicals has been a subject of much interest [3-5]. Even the induction of human cancer involves a multistep process, initiated with DNA damage by endogenous ROS and exogenous activated carcinogens. This is followed by oncogene activation and tumor suppressor gene mutations, which finally lead to the alteration of different signaling pathways. Cell cycle arrest, apoptosis, cell proliferation, and cell differentiation are all mediated through signal transduction processes and appear to be important executive targets for cancer chemoprevention.

Intensive efforts are being made to discover newer antioxidants with greater efficiency to intercept the processes of oxidative stress. In this connection, minor dietary constituents, especially plant-

\footnotetext{
*Paper based on a presentation at the $24^{\text {th }}$ International Symposium on the Chemistry of Natural Products and the $4^{\text {th }}$ International Congress on Biodiversity, held jointly in Delhi, India, 26-31 January 2004. Other presentations are published in this issue, pp. 1-344.

¥Corresponding author
} 
based foods, have come under intensive scrutiny [6]. Phytopolyphenols are widespread in the plant kingdom and are important not only for contributing to the flavor and color of many fruits and vegetables, but are also playing a crucial role in cancer chemoprevention. The important groups of phytopolyphenols in food are flavonoids and isoflavonoids, which comprise flavones, flavanones, flavonols, isoflavones, and anthocyanidines. We have investigated the antioxidant effects of different classes of polyphenolics.

\section{COUMARINS}

Coumarins are widely distributed in the plant kingdom, and 4-methylcoumarins are claimed to display various beneficial pharmacological properties [7-10].

We have, for the first time, isolated analogs of 4-methylcoumarins, i.e., troupin (4-methyl-6-hydroxy-7,8-dimethoxycoumarin) [11] and trigocoumarin [3-(ethoxycarbonyl)methyl-4-methyl-5,8dimethoxycoumarin] [12] from Tamarix troupii and Trigonella foenumgraecum, respectively. The leaves of $T$. troupii are used for the treatment of dysentery, chronic diarrohea, and leucoderma, while the seeds of T. foenumgraecum are used for treating colic, dysentery, chronic cough, and diabetes [13]. Unsubstituted coumarins have been found to be toxic since they undergo oxidative decarboxylation, to form very stable complexes with heavy metals inside the body [14]. On the other hand, 4-methylcoumarins are found to be resistant to oxidative decarboxylation and, hence, are nontoxic. In recent years, our laboratory has been engaged in studying the chemistry and biological effects of 4-methylcoumarin derivatives $1[15,16]$. We have systematically studied the effects of acetoxy, hydroxy, and methoxy substituents in a wide variety of 4-methylcoumarin derivatives on initiation, propagation, and chain termination of lipid peroxidation in rat liver microsomes [17].

The inhibitory effects of monohydroxy- or monoacetoxycoumarins were very marginal, though there was a quantum jump in the potency of dihydroxy and diacetoxy derivatives $\mathbf{2 - 6}$ to retard the initiation of lipid peroxidation. 4-Methylcoumarins 2-6, having two hydroxy or two acetoxy groups in the benzenoid ring at positions ortho to each other, have shown strong antioxidant and radical scavenging properties [17], and inhibition of TNF- $\alpha$ induced intercellular adhesion molecule-1 (ICAM-1) expression on endothelial cells (unpublished results). These compounds could suppress nearly $90 \%$ of lipid peroxidation. In addition, these dihydroxy- and diacetoxycoumarins were found to possess the ability to terminate the radical chain reaction and propagation of lipid peroxidation and also exhibited excellent radical scavenging potency. Moreover, dihydroxy- and diacetoxy thiocoumarins 7 were found to possess better inhibitory activity than the corresponding dihydroxy- and diacetoxycoumarins $\mathbf{2}-\mathbf{3}$ (unpublished results). 
<smiles>[R]c1c([R])c([R])c2c(C)c([R])c(=O)oc2c1[R]</smiles><smiles>Cc1cc(=O)oc2c(O)c(O)ccc12</smiles><smiles>CC(=O)Oc1cc2oc(=O)cc(C)c2cc1OC(C)=O</smiles>
5<smiles>CCOC(=O)CCc1c(C)c2cc(OC(C)=O)c(OC(C)=O)cc2oc1=O</smiles>
6

$$
\mathrm{R}^{1}=\mathrm{H} /-\mathrm{CH}_{2} \mathrm{CO}_{2} \mathrm{Et} /-\mathrm{CH}_{2} \mathrm{CH}_{2} \mathrm{CO}_{2} \mathrm{Et} /-\mathrm{Ph} /-\mathrm{C}_{6} \mathrm{H}_{4}-\mathrm{Br} /-\mathrm{C}_{6} \mathrm{H}_{4}-\mathrm{NO}_{2}
$$$$
\mathrm{R}^{2}, \mathrm{R}^{3}, \mathrm{R}^{4}, \mathrm{R}^{5}=\mathrm{H} /-\mathrm{OH} /-\mathrm{OCH}_{3} /-\mathrm{OCOCH}_{3} /-\mathrm{Br}
$$<smiles>CC(=O)Oc1ccc2c(C)cc(=O)oc2c1OC(C)=O</smiles><smiles>CCOC(=O)CCc1c(C)c2ccc(OC(C)=O)c(OC(C)=O)c2oc1=O</smiles>

4<smiles>O=C1OC(C(O)CO)C(O)=C1O</smiles>

Ascorbic acid<smiles>[R]c1ccc2c(C)cc(=S)oc2c1[R]</smiles>

7

$$
\mathrm{R}=\mathrm{OH} / \mathrm{OAc}
$$

We have proposed a mechanism of action for their antioxidant effect (Scheme 1) [17]. It is quite clear that such resonance-stabilized radicals in differently substituted flavonoids are known to confer radical scavenging properties on flavonoids. We believe that there exists the possibility of the conversion of DAMC (7,8-diacetoxy-4-methylcoumarin) 3 to DHMC (7,8-dihydroxy-4-methylcoumarin) 2 in the presence of the initiating free radical, such as peroxy radical or superoxide radical through the formation of reactive ketene (Scheme 1). 
<smiles>CC(=O)Oc1ccc2c(C)cc(=O)oc2c1OC(C)=O</smiles><smiles>CC(=O)Oc1c(O)ccc2c(C)cc(=O)oc12</smiles>

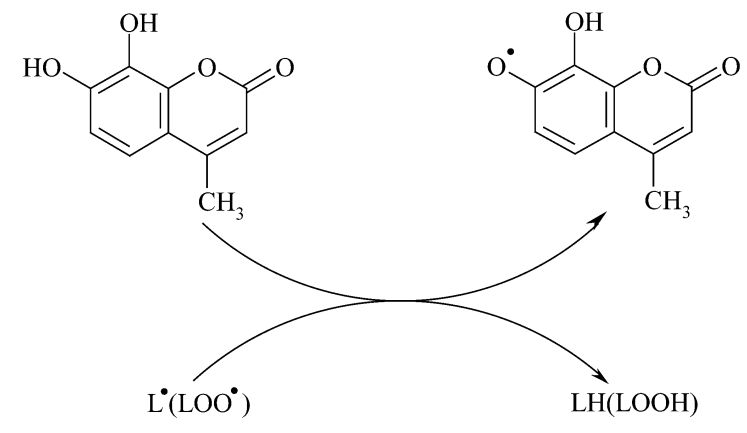

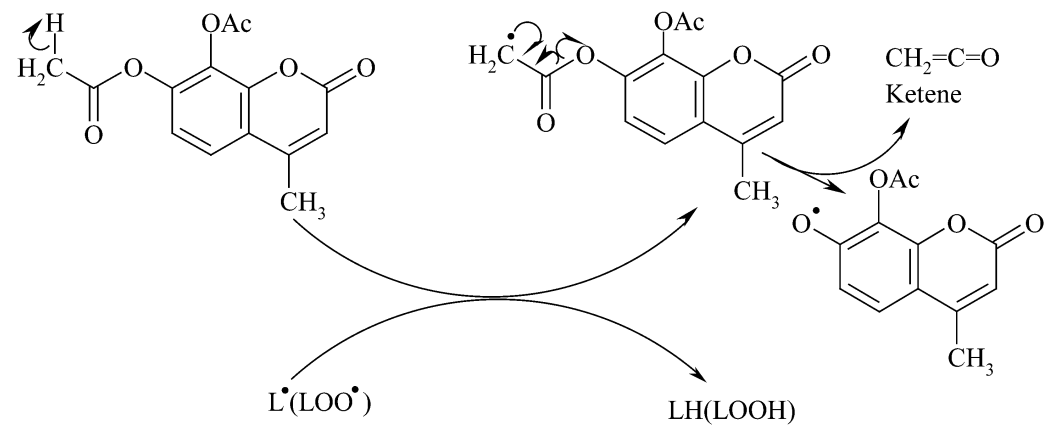

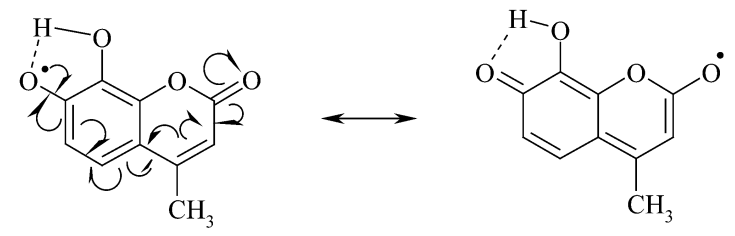

Reduced form of lipids: $\mathbf{L H} / \mathbf{L O O H}$

Oxidized form of lipids: $\mathbf{L}^{*} / \mathbf{L O O}$ radicals

Scheme 1 Suggested mechanism of lipid superoxide-mediated radical formation from DAMC and DHMC.

These properties of the coumarin derivatives highlight them as superb antioxidants. Investigations on several types of flavonoids point to the fact that the catechol moiety in these structures contributes to the antioxidant activity [18-20]. The reason for this strong antioxidant activity of ortho or peri dihydroxy systems can be explained by taking into account the stability of the transient seminquinone radical formed after the $\mathrm{H}$-atom transfer to a free radical. The intramolecular hydrogen bond in the radical, in fact, is several $\mathrm{kcal} / \mathrm{mol}$ stronger than in the parent phenol (Scheme 2) [21]. Of the different dihydroxy- and diacetoxy-4-methyl coumarins, 7,8-dihydroxy- (DHMC, 2) and 7,8-diacetoxy-4-methylcoumarin (DAMC, 3) possess maximum radical scavenging property (Table 1). We have also used the $\mathrm{pH}$ metric techniques to study the mechanistic action of DAMC and DHMC to inhibit lipid peroxidation. These studies confirm the formation of a stable ADP-Fe-inhibitor (e.g., ADP-Fe-DHMC) mixed 


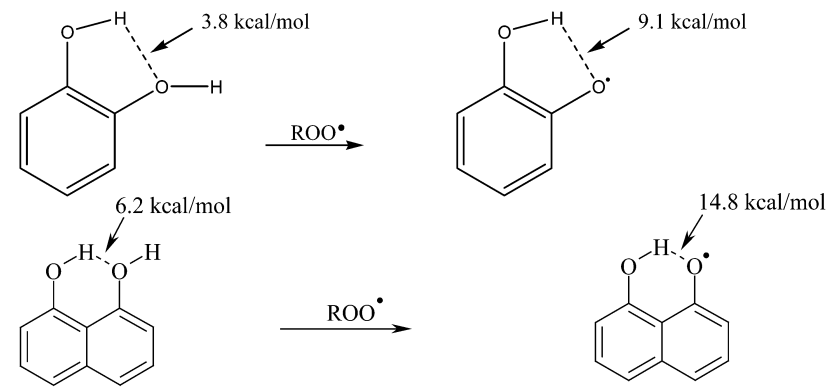

Scheme 2 Description of stability of phenoxy radical via hydrogen bonding.

ligand complex, thereby inhibiting the formation of ROS responsible for lipid peroxidation [22]. Further, pulse radiolysis studies were undertaken to explain the antioxidant action of DAMC. Accordingly, DAMC and DHMC were separately reacted with the system generating azide radicals and the resulting transient spectra were recorded [23].

Table 1 Radical scavenging potential of diacetoxy- and dihydroxy-4methylcoumarins.

\begin{tabular}{lc}
\hline Compound & $\begin{array}{c}\text { Scavenging of DPPH } \\
\mathrm{IC}_{50}(\mu \mathrm{M})\end{array}$ \\
\hline 7,8-Dihydroxy-4-methylcoumarin (2) & 14 \\
7,8-Diacetoxy-4-methylcoumarin (3) & 31 \\
7,8-Diacetoxy-3-(ethoxycarbonyl)ethyl-4- & 85 \\
methylcoumarin (4) & 31 \\
6,7-Diacetoxy-4-methylcoumarin (5) & 172 \\
6,7-Diacetoxy-3-(ethoxycarbonyl)ethyl-4- & \\
methhylcoumarin (6) & 35 \\
Ascorbic acid & \\
\hline
\end{tabular}

DPPH: Diphenylpicrylhydrazyl reagent

We have proposed that the mechanisms of scavenging of ROS by DAMC and DHMC are similar [23]. Further work to support this generalization is in progress. However, the results given in Table 2 confirm our observation that both the compounds $\mathbf{2}$ and $\mathbf{3}$ scavenge superoxide radicals very efficiently. These results suggest that the free radical-mediated oxidation of DAMC and DHMC initially produces a radical cation that may lose an acetyl carbocation or a proton, respectively, to produce similar kind of phenoxy radicals (Scheme 3).

Table 2 Scavenging of superoxide radical by DHMC and DAMC $^{\mathrm{a}}$.

\begin{tabular}{lcc}
\hline & $\begin{array}{c}\text { Cytochrome C reduced } \\
(\mu \mathrm{mol} / \mathrm{min})\end{array}$ & $\begin{array}{c}\text { Superoxide scavenging } \\
(\text { no. of folds })\end{array}$ \\
\hline Control & 2730 & 0 \\
DAMC & 633 & 4.31 \\
DHMC & 793 & 3.44 \\
\hline
\end{tabular}

aSuperoxide radical generated during the reaction catalyzed by xanthine oxidase is utilized for the scavenging action of the test compounds. The values expressed are mean of three experiments with variation $<5 \%$. 
<smiles>Cc1cc(=O)oc2c(O)c(O)ccc12</smiles><smiles>Cc1cc(=O)oc2c(O)c(O)ccc12</smiles><smiles></smiles>
phenoxyl radical

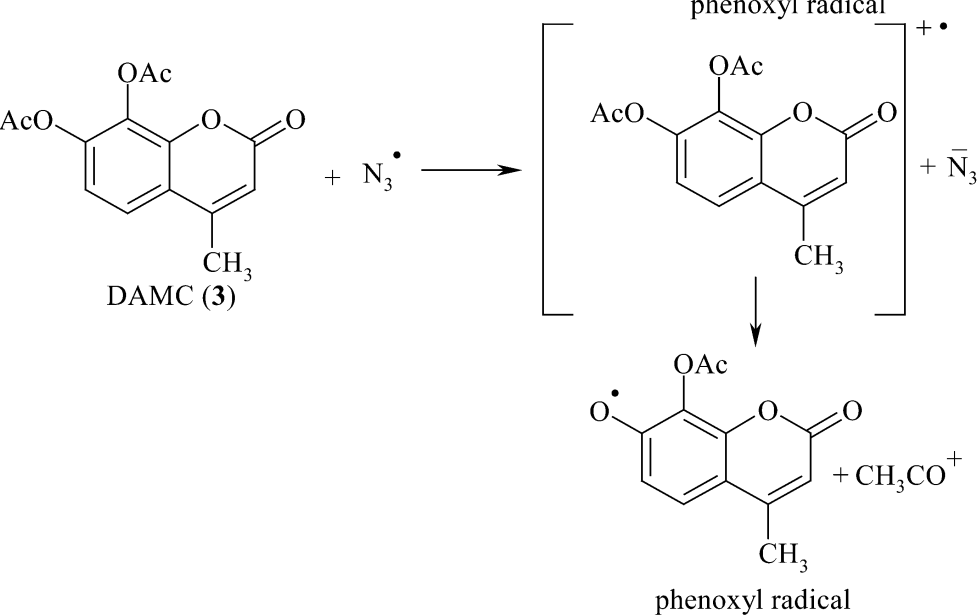

Scheme 3 Comparison of azide free radical interactions with DHMC and DAMC.

We have further extended our studies and synthesized a new series of 4-methylcoumarin derivatives bearing different functionalities viz. halo, unsaturated hydrocarbon chains, etc. They have been screened for the evaluation of their antioxidant activities by $\beta$-carotene-linoleate model system [24]. This test system too has established that the antioxidant activity of monohydroxycoumarins is less than that of dihydroxycoumarins (unpublished results).

\section{XANTHONES}

ROS are primary signaling molecules in regulating the expression of various cell adhesion molecules, especially ICAM-1 on endothelial cells. The higher expression of ICAM-1 leads to increased infiltration of proinflammatory leukocytes, especially neutrophils, at the site of immune activation and hence plays an important role in various inflammatory diseases [25,26]. Xanthones inhibit lipid peroxidation and influence the generation of ROS that in turn leads to the decreased expression of cell adhesion molecule and, subsequently, decreased inflammation [27,28]. These facts led us to investigate the mechanisms underlying the anti-inflammatory activities of xanthones and their structure-activity relationship. We have synthesized various hydroxy-, acetoxy-, and methoxyxanthones 8-15 and studied their effect on the initiation of lipid peroxidation in liver microsomes to examine their antioxidant properties and TNF- $\alpha$ induced expression of ICAM-1 on endothelial cells (Table 3) $[29,30]$. 
<smiles></smiles><smiles>O=c1c2ccc(O)cc2oc2ccc(O)cc12</smiles>

11<smiles>O=c1c2ccccc2oc2cc(O)ccc12</smiles><smiles>O=c1c2ccccc2oc2c(O)ccc(O)c12</smiles><smiles>CC(=O)Oc1ccc2oc3ccccc3c(=O)c2c1OC(C)=O</smiles><smiles>COc1ccc2c(=O)c3ccccc3oc2c1</smiles>

13<smiles>COc1ccc2c(=O)c3c(O)cccc3oc2c1O</smiles>

15

Table 3 Effect of xanthones on NADPH-dependent inhibition of lipid peroxidation initiation and TNF- $\alpha$ induced expression of ICAM-1 on endothelial cells.

\begin{tabular}{lcc}
\hline Compound name & $\begin{array}{c}\text { NADPH-dependent lipid } \\
\text { peroxidation initiation, } \\
\text { percent of the control }\end{array}$ & $\begin{array}{c}\text { \% Inhibition of } \\
\text { ICAM-1 } \\
\text { expression }\end{array}$ \\
\hline 1-Hydroxyxanthone(8) & 28 & 22.2 \\
3-Hydroxyxanthone (9) & 38 & 13.7 \\
1,4-Dihydroxyxanthone (10) & 60 & 86.0 \\
2,6-Dihydroxyxanthone (11) & 43 & 40.9 \\
1,2-Diacetoxyxanthone (12) & 30 & 42.4 \\
3-Methoxyxanthone (13) & 2 & 23.8 \\
1,3,7-Trimethoxyxanthone (14) & 0 & 0 \\
1,5-Dihydroxy-6-methoxyxanthone (15) & - & 1.6 \\
\hline
\end{tabular}

Monohydroxyxanthones showed high-to-moderate activity (Table 3). On the other hand, the dihydroxyxanthones showed increased activity as compared to monohydroxyxanthones. The xanthones 13-15 having methoxy groups did not show any appreciable inhibition of initiation of lipid peroxidation or ICAM-1 expression. Further, it has been found that the inhibition of initiation of lipid peroxidation by 1,2-diacetoxyxanthone is comparable with that of 1-hydroxyxanthone 8 [29]. The lipid peroxidation activity of diacetoxy-xanthone $\mathbf{1 2}$ may be because of in situ enzymatic deacetylation of this compound leading to the formation of the corresponding dihydroxyxanthone. This in turn may be oxidized to the corresponding quinonoid species 12a, which may be responsible for the observed activities. Monohydroxyxanthones $\mathbf{8}$ and $\mathbf{9}$ do not show any activity due to their inability to form the corresponding quinonoid xanthones. In the case of dihydroxyxanthones, the stability of the orthoquinonoid species 12a is less than that of the para-quinonoid species 10a. Therefore, compound 10 exhibited maximum activity. Also, we have recently demonstrated that the compound $\mathbf{1 0}$ blocked the adhesion of peripheral neutrophils to human vein endothelial cell monolayers [30]. Surprisingly, the xanthone 15, in spite of having two hydroxy groups, does not exhibit any noticeable activity, which may be because of the fact that this compound cannot oxidize, consequently, no quinonoid structure form can be generated. 
<smiles>O=C1C=CC(=O)c2c1oc1ccccc1c2=O</smiles>

$10 \mathrm{a}$<smiles>O=C1C=Cc2oc3ccccc3c(=O)c2C1=O</smiles>

12a

\section{PYRAZOLES AND ACRYLONITRILES}

Owing to the widespread uses of pyrazole derivatives in medicine [31-37] and other areas of human activity [38-44], we have synthesized and evaluated the antioxidant activities of a large number of pyrazoles and their derivatives [45]. These include novel classes of heterocyclic compounds, i.e., pyranones (lactones) 16, 5-aryl- pyrazoles 17, 1,3-diarylpyrazoles 20, and acrylonitriles 18, 19, and 21.<smiles>[R]c1cc([Si])c(C#N)c(=O)o1</smiles>

16<smiles>[R]c1cc(/C=C/c2ccc[nH]2)n[nH]1</smiles>

18<smiles>[R]c1ccc(-c2cc(CC#N)n(-c3ccc([R])cc3)n2)cc1</smiles><smiles>[R]c1cc(CC#N)n[nH]1</smiles><smiles>[R]c1cc(/C(C#N)=C\c2ccc[nH]2)n[nH]1</smiles>

19<smiles>[R]c1ccc(-c2cc(/C(C#N)=C/C=NC)n(-c3ccc([R])cc3)n2)cc1</smiles>

\begin{tabular}{c|ll}
$\mathbf{2 0 - 2 1}$ & $\mathbf{R}$ & $\mathbf{R}^{\prime}$ \\
\hline $\mathbf{a}$ & $\mathrm{H}$ & $\mathrm{H}$ \\
$\mathbf{b}$ & $\mathrm{Me}$ & $\mathrm{H}$ \\
$\mathbf{c}$ & $\mathrm{Cl}$ & $\mathrm{H}$ \\
$\mathbf{d}$ & $\mathrm{Br}$ & $\mathrm{F}$ \\
& & \\
& &
\end{tabular}

We have investigated the structural influence of the pyranone and pyrazole derivatives upon both initiation and propagation steps. Pyrazolylacrylonitriles have neither radical scavenging ability, nor can they inhibit mixed function oxidase (MFO) (data not shown). However, the possibility exists that pyrazolylacrylonitriles form a stable complex with ADP-perferryl radical responsible for ROS forma- 
tion as seen earlier in the case of dioxygenated 4-methylcoumarins [22]. NADPH-dependent liver microsomal lipid peroxidation was assayed by the method of Ernster and Nordenbrand [46]. The results illustrated that pyranones did not exhibit significant activity to inhibit the initiation of NADPH-catalyzed peroxidation of lipids of rat liver microsomes, whereas the conversion of pyranones to arylpyrazoles and to 1,3-diaryl pyrazoles increased the activity by 0 - to 11-fold in different cases (Tables 4 and 5). The maximum increase in activity has been observed in pyrazoles with unsubstituted phenyl ring/rings derived from the corresponding pyranones. In addition, methyl- or methoxyphenylpyrazolylacrylonitriles are found to have better antioxidant activity than unsubstituted, or fluoro- or chlorosubstituted phenylpyrazolylacrylonitriles.

Table 4 Inhibitory effect of pyranones and cyanomethylpyrazoles on lipid peroxidation in rat liver microsomes initiated by NADPH.

\begin{tabular}{lccc}
\hline Compound & $\begin{array}{c}\text { \% Inhibition } \\
\text { of initiation }\end{array}$ & Compound & $\begin{array}{c}\text { \% Inhibition } \\
\text { of initiation }\end{array}$ \\
\hline $\mathbf{1 6 a}$ & 3 & $\mathbf{1 7 d}$ & 27 \\
$\mathbf{1 6 b}$ & 14 & $\mathbf{1 7 e}$ & 33 \\
$\mathbf{1 6 d}$ & 4 & $\mathbf{1 7 f}$ & 10 \\
$\mathbf{1 6 g}$ & 14 & $\mathbf{1 7 h}$ & 18 \\
$\mathbf{1 6 h}$ & 18 & $\mathbf{2 0 a}$ & 33 \\
$\mathbf{1 7 a}$ & 33 & $\mathbf{2 0 b}$ & 33 \\
$\mathbf{1 7 b}$ & 31 & $\mathbf{2 0 c}$ & 26 \\
$\mathbf{1 7 c}$ & 35 & & \\
\hline
\end{tabular}

Table 5 Inhibitory effect of 2-pyrazolyl-3-(pyrrol-2yl)acrylonitriles on lipid peroxidation in rat liver microsomes initiated by NADPH.

\begin{tabular}{lccc}
\hline Compound & $\begin{array}{c}\text { \% Inhibition } \\
\text { of initiation }\end{array}$ & Compound & $\begin{array}{c}\text { \% Inhibition } \\
\text { of initiation }\end{array}$ \\
\hline 18a & 53 & $\mathbf{1 8 f}$ & 42 \\
$\mathbf{1 9 a}$ & 73 & $\mathbf{1 9 f}$ & 68 \\
$\mathbf{1 8 b}$ & 69 & $\mathbf{1 8 g}$ & 27 \\
$\mathbf{1 9 b}$ & 95 & $\mathbf{1 9 g}$ & 90 \\
$\mathbf{1 8 c}$ & 52 & $\mathbf{1 8 h}$ & 77 \\
19c & 67 & $\mathbf{1 9 h}$ & 68 \\
$\mathbf{1 8 d}$ & 20 & $\mathbf{2 1 a}$ & 36 \\
19d & 62 & $\mathbf{2 1 b}$ & 48 \\
18e & 42 & $\mathbf{2 1 c}$ & 87 \\
19e & 69 & $\mathbf{2 1 d}$ & 80 \\
\hline
\end{tabular}

\section{CONCLUSION}

A wide variety of compounds have been synthesized and subjected to screening of their activity as antioxidants for the inhibition of NADPH-catalyzed peroxidation of rat liver microsomes and/or inhibition of cytokine-induced ICAM-1 expression, which has led to the identification of potent antioxidant compounds. This study may be a significant pointer in the development of clinical antioxidant agents. 


\section{ACKNOWLEDGMENTS}

We thank the Council of Scientific and Industrial Research (CSIR, New Delhi, India) and Consiglio Nazionale delle Ricerche (CNR, Rome, Italy) for financial support.

\section{REFERENCES}

1. J. A. Buege and S. D. Aust. Methods Enzymol. 30, 302 (1978).

2. G. G. Duthie. Eur. J. Clin. Nutr. 47, 759 (1993).

3. R. G. Cutler. Free Radicals in Biology, W. A. Pryor (Ed.), Academic Press, London, 6, Chap. 11 (1984).

4. R. J. Melhorn and G. Cole. Advances in Free Radical Biology and Medicine, Pergamon Press, Oxford, 1, 165 (1985).

5. R. S. Sohal and R. G. Allen. Advances in Free Radical Biology and Medicine, Pergamon Press, Oxford, 2, 117 (1986).

6. B. Halliwell. Free Rad. Res. Commun. 34, 1013 (1996).

7. S. Takeda and M. J. Aburada. Pharmacobiodyn. 4, 724 (1981).

8. C. H. Yang, C. Chiang, K. Liu, S. Peng, R. Wang. Chem. Abstr. 95, 161758 (1981).

9. A. Tyagi, V. P. Dixit, B. C. Joshi. Naturwissenschaftten. 67, 104 (1980).

10. A. A. Deana. J. Med. Chem. 26, 580 (1983).

11. V. S. Parmar, J. S. Rathore, S. Singh, A. K. Jain, S. R. Gupta. Phytochemistry 24, 871 (1985).

12. V. S. Parmar, H. N. Jha, S. K. Sanduja, R. Sanduja. Z. Naturforsch. 37B, 521 (1981).

13. Y. Sauvaire, P. Petit, C. Broca, M. Manteghetti, Y. Baissac, J. F. Alvarez, R. Gross, M. Roye, A. Leconte, R. Gomis, G. Ribes. Diabetes 47, 206 (1998).

14. B. G. Lake. Food Chem. Toxicol. 37, 423 (1997).

15. H. G. Raj, S. Gupta, A. K. Prasad, P. M. Boll, J. Wengel, G. Biswas, S. K. Singh, N. K. Sharma, K. S. Bisht, V. S. Parmar. Bioorg. Med. Chem. Lett. 5, 1567 (1995).

16. H. G. Raj, S. Gupta, G. Biswas, S. Singh, A. Singh, A. Jha, K. S. Bisht, S. K. Sharma, S. C. Jain, V. S. Parmar. Bioorg. Med. Chem. 4, 2225 (1996).

17. H. G. Raj, V. S. Parmar, S. C. Jain, S. Goel, Poonam, Himanshu, S. Malhotra, A. Singh, C. E. Olsen, J. Wengel. Bioorg. Med. Chem. 6, 833 (1998).

18. S. R. Husain, J. Cillard, P. Cillard. Phytochemistry 26, 2489 (1987).

19. M. Yones and C. P. Seigers. Planta Medica 43, 240 (1981).

20. H. C. Jha, V. Recklinghausen, F. Zelliken. Biochem. Pharmacol. 34, 1367 (1985).

21. M. C. Foti, E. R. Johnson, M. R. Vinqvist, J. S. Wright, L. R. C. Barclay, K. U. Ingold. J. Org. Chem. 67, 5190 (2002).

22. H. G. Raj, R. K. Sharma, B. S. Garg, V. S. Parmar, S. C. Jain, S. Goel, Y. K. Tyagi, A. Singh, C. E. Olsen, J. Wengel. Bioorg. Med. Chem. 6, 2205 (1998).

23. H. G. Raj, V. S. Parmar, S. C. Jain, K. I. Priyadarsini, J. P. Mittal, S. Goel, S. K. Das, S. K. Sharma, C. E. Olsen, J. Wengel. Bioorg. Med. Chem. 7, 2091 (1999).

24. G. K. Jayaprakasha, R. P. Singh, K. K. Sakariah. Food Chem. 73, 285 (2001).

25. S. Cuzzocrea, E. Mazzon, L. Dugo, I. Serranio, A. Ciccolo, T. Centorrino, A. Sarro, A. P. Caputi. FASEB J. 15, 1187 (2001).

26. M. Walther, W. Kaffenberger, D. van Beuningen. Int. J. Radiat. Biol. 75, 1317 (1999).

27. J. P. Wang, S. L. Raung, C. N. Lin, C. M. Teng. Eur. J. Pharmacol. 251, 35 (1994).

28. C. N. Lin, M. I. Chung, S. J. Liou, T. H. Lee, J. P. Wang. J. Pharm. Pharmacol. 48, 532 (1996).

29. B. Madan, I. Singh, A. Kumar, A. K. Prasad, H. G. Raj, V. S. Parmar, B. Ghosh. Bioorg. Med. Chem. 10, 3431 (2002).

30. B. Madan, A. K. Prasad, V. S. Parmar, B. Ghosh. Bioorg. Med. Chem. 12, 1431-1437 (2004). 
31. R. H. Wiley and P. Wiley. Pyrazolones, Pyrazolidones and Derivatives, p. 102, John Wiley, New York (1964).

32. G. Rainer, U. Krueger, K. Klemm. Arzneim.-Forsch. 31, 649 (1981); Chem. Abstr. 95, 90723 (1981).

33. C. E. Rosiere and M. I. Grossman. Science 113, 651 (1951).

34. D. M. Bailey, P. E. Hansen, A. G. Hlavac, E. R. Baizman, J. Pearl, A. F. Defelice, M. E. Feigenson. J. Med. Chem. 28, 256 (1985).

35. M. Kurowaski, A. Dunky, M. Geddawi. Eur. J. Clin. Pharmacol. 26, 481 (1988).

36. K. Seki, T. T. Watanabe, T. Suga. Chem. Pharm. Bull. 36, 1117 (1988).

37. R. N. Mahajan, F. H. Havaldar, P. S. Fernandes. J. Indian Chem. Soc. 68, 245 (1991).

38. H. Suzuki, M. Hanaue, M. Nishikubo. Jpn. Kokai Tokyo Koho JP, 03, 236, 368; Chem. Abstr. 116, 106285 (1993).

39. B. Natsume, N. Kyomura, K. Kikutake, T. Fukuch. Eur. Pat. Appl. EP., 462, 573; Chem. Abstr. 116, 128916 (1992).

40. M. Londershausen. Pestic. Sci. 48, 269 (1996).

41. B. S. M. Fahmy and M. H. Elnagdi. J. Chem. Tech. B: Technol. 30 (1980); Chem. Abstr. 94, 48804 (1981).

42. The Chemistry of Synthetic Dyes and Pigments, H. A. Lubs (Ed.), American Chemical Society, Washington (1970).

43. H. Garcia, S. Iborra, M. A. Miranda, I. M. Morera, J. Primo. Heterocycles 32, 1745 (1991).

44. A. I. Busev, V. K. Akimov, S. I. Gusev. Russ. Chem. Rev. (Eng. Transl.) 34, 237 (1965); Chem. Abtsr. 62, 15395 (1965).

45. V. S. Parmar, A. Kumar, A. K. Prasad, S. K. Singh, N. Kumar, S. Mukherjee, H. G. Raj, S. Goel, W. Errington, M. S. Puar. Bioorg. Med. Chem. 7, 1425 (1999).

46. L. Ernster and K. Nordenbrand. Methods Enzymol. 10, 574 (1967). 